Review

\title{
How Eco-Efficient Are Low-Input Cropping Systems in Western Europe, and What Can Be Done to Improve Their Eco-Efficiency?
}

\section{Michal Kulak $^{1, *}$, Thomas Nemecek ${ }^{1}$, Emmanuel Frossard $^{2}$ and Gérard Gaillard ${ }^{1}$}

1 Life Cycle Assessment, Agroscope Reckenholz-Tänikon Research Station ART, Reckenholzstrasse 191, Zurich 8046, Switzerland; E-Mails: thomas.nemecek@agroscope.admin.ch (T.N.); gerard.gaillard@agroscope.admin.ch (G.G.)

2 Institute of Agricultural Sciences, ETH Zurich, Lindau 8315, Switzerland; E-Mail: emmanuel.frossard@usys.ethz.ch

* Author to whom correspondence should be addressed; E-Mail: michal.kulak@agroscope.admin.ch; Tel.: +41-443-777-326; Fax: +41-443-777-201.

Received: 15 July 2013; in revised form: 23 August 2013 / Accepted: 25 August 2013 /

Published: 4 September 2013

\begin{abstract}
Low-input cropping systems were introduced in Western Europe to reduce the environmental impacts of intensive farming, but some of their benefits are offset by lower yields. In this paper, we review studies that used Life Cycle Assessment (LCA) to investigate the effects of reducing external inputs on the eco-efficiency of cropping systems, measured as the ratio of production to environmental impacts. We also review various cropping system interventions that can improve this ratio. Depending on the initial situation and the impacts considered, reducing inputs will in itself either reduce or increase environmental impacts per product unit-highly eco-efficient cropping systems require application of optimum instead of minimum quantities of external inputs. These optimum rates can be lowered by utilizing positive synergies between crops to minimise waste of nutrients and water and by utilizing locally produced organic waste; both from within the farm as well as well as from the surrounding sociotechnical environment. Eco-efficiency can also be improved by increasing yields in a sustainable matter. Strategies such as breeding, increasing diversity, no-tillage or intercropping will not be effective under all conditions. LCA provides a useful framework to identify environmentally optimum levels of inputs and trade-offs between various intensification scenarios.
\end{abstract}


Keywords: low-input farming; eco-efficiency; cropping systems; environmental impacts; Life Cycle Assessment; sustainable intensification

\section{Introduction}

Following World War II, the Common Agricultural Policy and a number of national policies were introduced in Europe with the aim of increasing food security. This goal has been achieved with remarkable success in the western part of the continent, where it has been paired with rapid economic growth. Today, Western Europe is one of the world's most agriculturally productive regions, whose mean wheat yield between 1990 and 2011 was 2.5 times higher than the global average, and almost 3 times higher than Eastern Europe's [1]. During the second half of the 20th century, agricultural developments in Western Europe significantly increased land productivity whilst reducing agricultural labor requirements [2]. These productivity gains, however, were achieved at some external cost. It is well recognized that agricultural intensification was coupled with the increased use of synthetic fertilizers, pesticides and irrigation water, and that this created a number of sustainability challenges $[3,4]$. Concerns over the nutrient pollution and loss of ecosystem services caused by intensive production resulted in a renewed interest in, and public support for, more-extensive modes of production.

The term "low-input farming" has been in use since the 1980 s to describe farming systems aiming to minimise the consumption of farm-external inputs and maximize the use of internal resources, mainly understood as fertilizers, pesticides and energy [5-8]. Although some low-input producers also possess organic certificates, the terms "organic farming" and "low-input farming" should not be used interchangeably. The term low-input is not limited to farms that apply only organic nutrients. Organic farms, on the other hand, may have relatively high yields, but these may be coupled with high application levels of organic fertilizers and other permitted inputs that enable the plant environment to be regulated. By contrast, yields at low-input farms are limited by the availability of nutrients, water and an increased risk of losses from pest and diseases. Farmers following low-input methods often cultivate rare varieties of crops, including wild crop relatives and landraces, or develop their own cultivars. Although losses from pests and diseases can be partially offset by crops and varieties that have higher resistance [9], overall yield is expected to be lower because of the lower absolute yield potential [7]. Despite lower yields, it has been demonstrated that switching to low-input farming systems in Western Europe allow farmers to maintain their income due to reduced costs of inputs $[9,10]$. The European Environment Agency defines low-input farms as those spending less than $€ 80 \mathrm{ha}^{-1} \mathrm{a}^{-1}$ on fertilizers, crop protection and concentrated feedstuffs [11]. It has been estimated, that the share of such farms within the total agricultural area of the EU-12 increased from 26\% to 28\% between 1990 and 2010 [11].

The cropping system is defined as a piece of land that is managed homogeneously for crop production, i.e., with the same crops, in the same rotation and using the same technical means [12]. The term "eco-efficiency" was originally used to describe the production of "competitively priced goods and services that satisfy human needs and bring quality of life while progressively reducing environmental impacts and resource intensity throughout the entire life-cycle to a level at least in line with the Earth's estimated carrying capacity" [13]. This concept appears to be highly relevant 
for modern agriculture, which is facing many sustainability challenges. Recent food-commodity price spikes brought productivity issues back to the top of political and research agendas. Sustainable Intensification (SI) became one of the strategic goals of the FAO and a number of other organizations [14-16] which called for an increase in global food production on existing agricultural land with a simultaneous reduction of its impacts on the environment [16-18]. The term "intensification" emphasizes the necessity of achieving productivity increases, but global SI does not mean that yields must be increased in all regions [19]. Western Europe is one of the few areas in the world where maintaining or slightly reducing levels of production would probably not compromise long-term food security goals, but intensive agricultural systems have already caused significant damage to the environment. In this part of the world, it is therefore reasonable to pursue improvements in eco-efficiency rather than sole yield increases.

Eco-efficiency can be expressed in quantitative terms as an economic value divided by an environmental impact [20]. In this study, we looked at the changes in product quantity, assuming that the rate of change in product quantity at a constant price will correspond to the rate of change in monetary value. At present, Life Cycle Assessment (LCA) is the most standardized and widely applied method allowing for quantifying of environmental impacts of products, services and activities throughout their life cycles [21]. LCA can be applied to evaluate cropping systems by using the ratio of quantitative environmental indicators to productive functional units, thereby allowing the systematic comparison of eco-efficiency between systems. LCA is widely applied in the agri-food sector [22]. One of the most common uses of this method has been the comparison of environmental impacts at farm scale between organic and conventional farming systems, as illustrated in a recent meta-analysis dedicated to this subject [23]. To date, far less research has been devoted to the evaluation of cropping systems with different levels of external inputs, and to identifying practical solutions for their improvement.

The objectives of this paper are twofold:

(1) to review the evidence from Life Cycle Assessment (LCA) regarding the effect of reducing agricultural inputs on eco-efficiency; and

(2) to identify interventions for improving eco-efficiency of low-input cropping systems.

\section{Methodology}

Goal and scope definition is the first step of all LCA studies [24], since it determines the assumptions and methodological choices. For the purpose of achieving the first objective of this review, we selected studies from the LCA literature that were solely dedicated to comparing cropping systems at different fertilization levels. Since LCA studies are spatially explicit [25], we included only those with the study subject located in Western Europe. In Haas et al.'s study, we excluded the impact categories of biodiversity, landscape image and animal husbandry, since these were expressed per farm, and were therefore not related to any uniform functional unit that would allow us to scale up or generalize the results. We also excluded results for the impact categories of groundwater quality and surface-water quality, as they were calculated as a function of nutrient use, and hence provided no additional information for this paper to the impact category "eutrophication". Due to the differing approaches that were used across studies to characterize land-use impacts, we used the impact category 
"land occupation" to ensure comparability. Defined as the surface area of agricultural land that must be occupied for one year to deliver the given functional unit, land occupation was calculated based on yield. To better illustrate the relationship between external input levels and eco-efficiency, we compiled LCA results for bread-wheat production from two independent studies [26,27] in graphic form. To allow comparability, original eutrophication units from Nemecek et al. [27] which were nitrogen equivalents were converted to phosphorus equivalents using conversion factors from Hauschild and Wenzel [28]. We also employed Agri-LCI models from Cranfield University [29,30] to estimate the environmental impacts of wheat production in the UK at fertilization levels corresponding to those of Brentrup et al. [26], and included these results for comparison. The list of potential strategies for improving eco-efficiency was compiled from review articles on sustainable intensification [14,16,31-38], and those for which LCA studies could be found were included in the review. Based on previous knowledge, we supplemented the list with nutrient-recycling technologies. It is worth mentioning that the list of techniques reviewed in this article is merely exemplary, and other, more effective techniques may exist. We used Agri-LCI models to simulate the consequences of reduction in tillage. For simplicity's sake, we limited the comparison to one impact category ("net greenhouse-gas balance") while discussing the environmental impacts of various feedstocks for anaerobic digestion. The article also discussed the impacts on other impact categories, and the full list of absolute numbers can be found in the original studies. In the final part of the article, we addressed some limitations of LCA methodology for assessing the performance of low-input systems.

\section{Environmental Impacts of Low-Input Cropping Systems}

Table S1 gives an overview of LCA studies from Western Europe on cropping systems with different levels of external inputs. Haas et al.'s study [39] showed a reduction in all environmental impacts except for land occupation per tonne of harvested grass when external input levels were reduced. However, the relative differences in mean yield in the study were comparatively low: $11.8 \mathrm{tha}^{-1}$ in the intensive, $10.5 \mathrm{t} \mathrm{ha}^{-1}$ in the extensified and $10.7 \mathrm{t} \mathrm{ha}^{-1}$ in the organic system. Although it is known that mineral fertilizers were used in the intensive and not in the extensified and organic systems, the rates of application of organic fertilizers were not reported. Brentrup et al.'s study [26] was based on a long-term field trial from the Rothamsted research station in the UK. Environmental impacts at seven different nitrogen $(\mathrm{N})$ fertilization levels were investigated, from 0 to $288 \mathrm{~kg} \mathrm{~N} \mathrm{ha}^{-1}$, with other inputs kept at constant rates. Environmental impacts per tonne of wheat were shown to decrease proportionally with decreasing levels of $\mathrm{N}$ for two of the analyzed impact categories: "Global Warming Potential" and "Eutrophication Potential". Despite this, energy use and acidification were shown to decrease and increase again when levels of $\mathrm{N}$ were too low. At a very high fertilization level, land occupation could be reduced by reducing N, but was generally observed to be increasing together with reduced inputs due to reduced yields. Charles et al. [40] performed a similar study in Switzerland in which four fertilization treatments for wheat were analyzed: $100 \mathrm{~kg} \mathrm{~N} \mathrm{ha}^{-1}, 140 \mathrm{~kg} \mathrm{~N} \mathrm{ha}^{-1}, 180 \mathrm{~kg} \mathrm{~N} \mathrm{ha}^{-1}$, and $220 \mathrm{~kg} \mathrm{~N} \mathrm{ha}^{-1}$, with $\mathrm{P}$ and $\mathrm{K}$ adjusted proportionally to nitrogen levels. All impact categories except for land occupation, eutrophication and aquatic ecotoxicity were shown to decrease per tonne of wheat grain when $\mathrm{N}$ was reduced. However, when $1 \mathrm{t}$ of wheat with constant protein content was used as a functional unit, nearly all environmental impacts increased along with a reduction in $\mathrm{N}$, owing to the positive relationship between $\mathrm{N}$ fertilization and protein content of grains. Nemecek et al. [27] showed 
that all impact categories except for land occupation were reduced or unaffected in a cash-crop rotation and a feed-crop rotation. In the grassland systems investigated, however, energy use, acidification, eutrophication, aquatic ecotoxicity, terrestrial ecotoxicity and human toxicity all increased along with a reduction in fertilization, and decreased again at very low levels of fertilization, while for ozone formation and GWP the opposite result was found - the highest environmental impacts were at the highest and lowest fertilization levels. Modeled cropping systems for winter wheat and barley showed increases per product unit for nearly all impact categories considered, except for those related to toxicity, and - in the case of rapeseed — ozone formation. When "Swiss Franc of revenue" was used as a functional unit, the result was more favorable for low-input production, partially owing to the direct payments for this type of cultivation in Switzerland. Glendining et al. [41] coupled LCA models from Williams et al. [29] with the economic valuation of ecosystem services. The starting point of the analysis was current levels of intensity in the UK, and several scenarios for nationwide reductions in inputs to wheat production were examined. The study showed that environmental damage to ecosystem services will increase for all products analyzed if farmers in the UK reduce input levels. This was owed to increasing land requirements, and agricultural land use was assigned a high environmental cost due to the potential damage caused to natural ecosystems. Goglio [42] investigated cropping systems for first-generation bioenergy production with different levels of external inputs in Italy, showing that environmental impacts per MJ of energy produced can be lowest at low levels of external inputs.

Figure 1 illustrates the correlations between nitrogen application to bread wheat and environmental impacts per tonne of harvested grain across different studies. It is worth mentioning that wheat has a strong response to $\mathrm{N}$ fertilization, and results for less demanding crops would probably be more favorable for low-input production. The results from both Williams et al. [29] and Brentrup et al. [26] reveal an optimum point for energy use at the moderate application rates, between 100 and $200 \mathrm{~kg}$, although there is a difference of a factor of 2 between the absolute values. Both studies show that reducing or increasing nitrogen below or above an optimum level will cause reductions in eco-efficiency. Nemecek et al.'s study [27] revealed a reduction in energy demand with increased fertilization rates, although the absolute levels of applied nitrogen remained below $200 \mathrm{~kg} \mathrm{~N} \mathrm{ha}^{-1}$. There is an obvious difference between organic and mineral fertilization, with the latter being characterized by higher energy demand. Brentrup et al.'s study [26] revealed a close-to-linear relationship between increased nitrogen levels and GWP, while in Williams et al. [29] this value remains constant at lower levels, followed by a rapid increase at higher levels of fertilization. Large differences between studies at lower fertilization levels are presumably due to differences in modeling assumptions for greenhouse-gas emissions from unfertilized soils. Although more dispersed, Nemecek et al.'s results [27] generally show increases along with increased fertilization. In both Williams et al. [29] and Brentrup et al. [26], eutrophication potential appears to remain steady or decrease slightly at lower fertilization rates, then increase at higher rates above $200 \mathrm{~kg} \mathrm{~N}$ per ha. Nemecek et al.'s results [27] show a much higher Eutrophication Potential for organic fertilization. Although Acidification Potential increases proportionally to nitrogen application in Williams et al.'s model [29], according to Brentrup et al. [26] it decreases slightly before increasing again. Nemecek et al.'s study [27] reveals higher results for the organically fertilized cases. The non-linearity of results shows the importance of factors other than quantity of $\mathrm{N}$-especially the form in which fertilizers are applied-for eco-efficiency results. 
Figure 1. The influence of fertilization rates on Life Cycle Assessment (LCA) results for bread wheat across Western European studies.
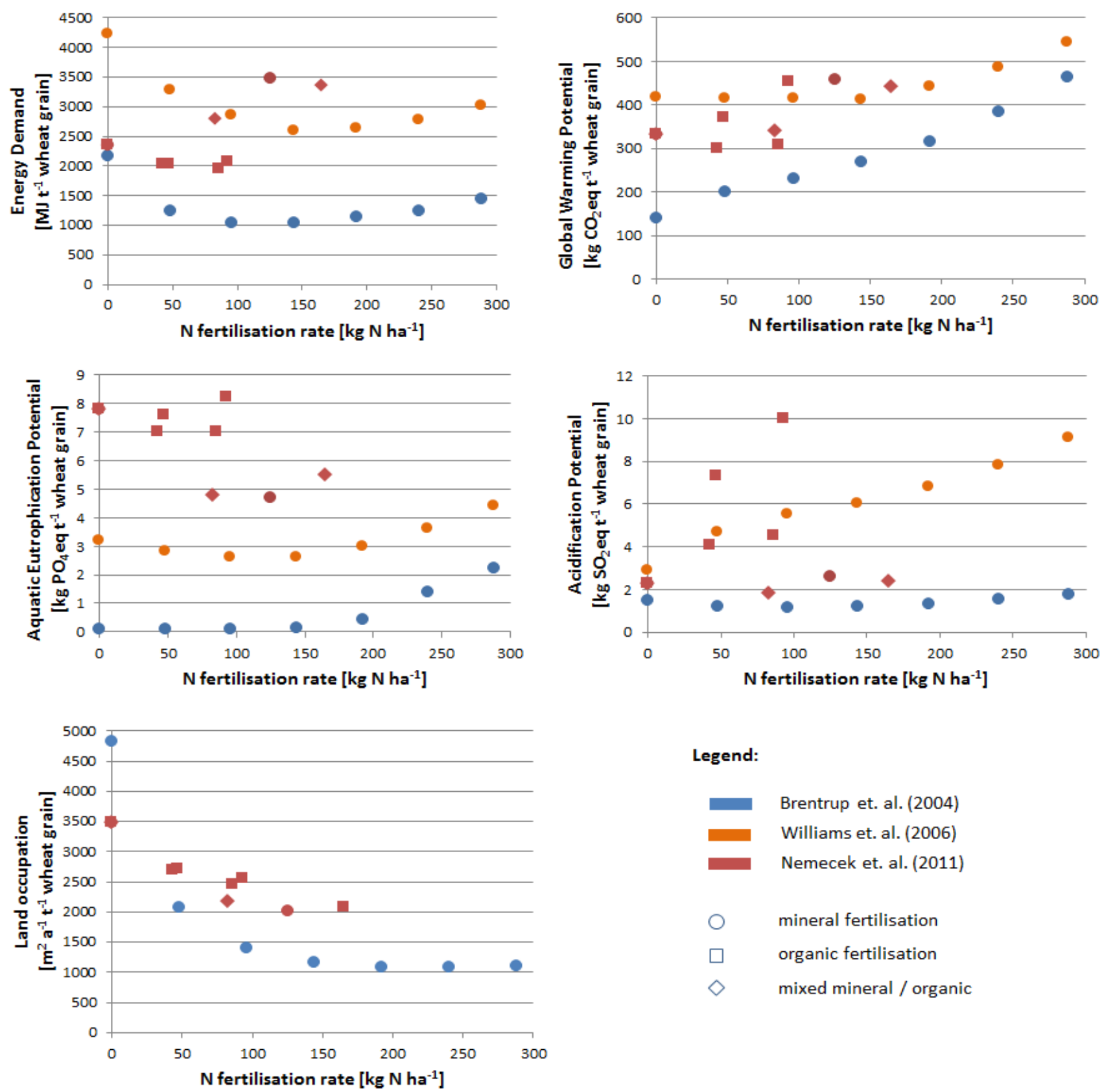

\section{How Can the Eco-Efficiency of Low-Input Cropping Systems Be Improved?}

As demonstrated in the previous paragraph, when input levels are too low, improvements in eco-efficiency can be achieved by increasing them to the optimum level. The mean $\mathrm{N}$ fertilization rate for arable crops in Western Europe between 2002 and 2010 was $123 \mathrm{~kg} \mathrm{~N}^{-1}$ [1]. Taking wheat production as an example (Figure 1), this appears to be within or even slightly below the optimum levels for eco-efficiency. This could lead to the conclusions that current fertilizer application levels are optimal, and that further reductions in inputs would generally increase the level of damage to ecosystem services [41]. Viewing eco-efficiency as a function of input levels is a simplification, however, since inputs to the production process can also be substituted. Since such a substitution will 
influence eco-efficiency, it is possible to manipulate this value by switching between different types of inputs instead of increasing them. Changing the crop from wheat to something less dependent on nitrogen fertilization provides more output from the same rate of natural resources invested, thereby increasing eco-efficiency.

Since reducing inputs almost always leads to higher land use per product unit, low-input systems are characterized by generally lower land use efficiency (Table S1). Any solution that creates a higher increase in yield than in the environmental impacts per area will therefore also result in eco-efficiency improvements. Literature on sustainable intensification provides examples of various cropping-system interventions that increase yields in a more sustainable manner than increasing fertilizers and pesticides [14,33]. Examples include breeding, conservation agriculture, species diversification, integrated pest and nutrient management systems, agroforestry, precision agriculture, reintegration of crop and livestock production, or mixing of cultivars and species. There is, however, limited empirical evidence as to whether and under what conditions these strategies can improve the eco-efficiency.

\subsection{Reduced Tillage, Conservation Tillage and No-Till Farming}

Crop-production technologies that reduce tillage and leave at least $30 \%$ of crop residues on the soil surface are referred to as conservation tillage [43]. Reduction in tillage is an essential component of a wider set of practices known as Conservation Agriculture (CA) [44]. A more specific system of sowing crops with less than $5 \mathrm{~cm}$ of disturbance to the soil structure and in which $30 \%-100 \%$ of the soil surface is covered with plant residues is known as no-till, direct drilling or zero tillage [45]. In the past, the adoption of no-till farming was believed to sequester atmospheric carbon and mitigate climate change [46,47]. Numerous LCA studies have been conducted that incorporate these effects into the greenhouse gas balance, mainly in the context of biofuel production [48-51]. Recently, however, these assumptions have been called into question, since no differences in carbon pool between the soil under no-till and conventional cultivation can systematically be observed when the entire soil profile is measured [52,53]. Table S2 reviews the results of LCA studies on the effects of no-tillage cultivation without assuming carbon sequestration benefits. Based on the results of a field experiment conducted in Switzerland, Nemecek et al. [27] showed that introducing no-till practices can reduce some environmental impacts such as human toxicity, but also increase others, like terrestrial ecotoxicity due to the necessity for the application of pesticides, and in addition may have no effect on eutrophication and GWP per product unit. The yield in the cropping-system experiment increased by $4 \%$ over that of conventional tillage, but this may be partially owing to the increase in $\mathrm{N}$ and $\mathrm{P}$ fertilization. Williams et al.'s model [29] assumes a need to increase various pesticides by $18 \%$ in order to maintain the same yield levels when adopting reduced-tillage practices. Modeling the switch from conventional to reduced-tillage practices reveals slight increases in the environmental impacts considered. In Iriarte et al.'s study [54] on rapeseed production in Chile, no-till practices reduced ozone formation potential by $40 \%$, but increased aquatic ecotoxicity by $650 \%$ due to the application of glyphosate. Studies conducted by Tuomisto [55] and van der Werf [56] revealed slight reductions in the environmental impacts.

All LCA studies considered here assumed no decrease in yields after the application of no-tillage systems. The adoption of these techniques could therefore be of interest to farmers, as they enable savings in diesel and labor associated with soil preparation. It should be borne in mind, however, that 
yields can also decline substantially following the adoption of no-tillage methods, especially when weed control by herbicides is not sufficient. Soane et al. [45] performed a meta-analysis of experiments conducted in Europe, in which yields from no-till and plough-based farming were compared. Their findings indicate that whilst the adoption of no-tillage in conventional agriculture can increase yields in dry regions of south-western Europe, no-till would most likely cause reductions in yield in northern Europe, with its higher annual rainfall. The key benefit of no-tillage is improved water retention of the soil. The adoption of this technique, however, requires effective weed control, which is a limiting factor for most European low-input farmers.

\subsection{Legumes and Crop Rotations}

Crop rotation can potentially improve yields in low-input cropping systems without increasing environmental burdens. This is mainly due to two effects: (i) the elimination or reduction of crop-specific pathogens (phytosanitary effects) or weeds; and (ii) Symbiotic or Biological Nitrogen Fixation (SNF/BNF) by leguminous crops. Some legumes can also improve phosphorus availability for the plants following them in the rotation [57-59], whilst others, such as alfalfa (Medicago sativa) can improve water uptake from the subsoil for the subsequent crops [60]. None of these mechanisms requires the investment of additional non-renewable resources, nor do any of them cause substantial emissions to the environment. Several LCA studies evaluated the effects of introducing legumes into cropping systems (Table S3). Nemecek et al. [61] quantified the effects of introducing peas into several crop rotations across Europe. Experiments in Germany and France showed a reduction in environmental impacts for most of the impact categories considered, due to the replacement of nitrogen fertilizers. The gross margin was also higher with grain legumes, despite the slightly lower grain yield which made these reductions even greater when quantified per financial functional unit. By contrast, the Swiss experiment showed an increase in GWP, eutrophication potential, terrestrial ecotoxicity, human toxicity, and land use per unit of harvested dry matter. This was because of the combined effect of lower physical yield from introduced crops and increased nitrate leaching. Nevertheless, most of the impact categories showed net reductions when quantified per unit of gross margin, owing to the higher financial yield. In a cropping system used in Spain, grain legumes were introduced into low-input crop rotation with sunflower. This led to increases in most of the environmental impacts considered, since no mineral fertilizer was replaced in the process. In one of the modeled scenarios, Tuomisto et al. [55] demonstrated that replacing all mineral fertilizer by leys in conventional crop rotation in the UK would reduce energy demand by $40 \%$ and GWP by $26 \%$, despite the reduction in absolute grain yield.

As previously mentioned, the ability of leguminous crops to fix nitrogen is not the only benefit of growing crops in rotation. Numerous experiments have shown that soybean yields are increased when this crop is grown in rotation with non-leguminous crops [62-66]. Changing from soybean to another crop breaks the lifecycle of soybean cyst nematodes (SCN's). Crop rotation was also shown to suppress "take-all", a major disease of wheat caused by the pathogen Gaeumannomyces graminis var tritici [67] and responsible for losses in temperate climates. Some wheat pathogens such as Rhizoctonia solani, however, have a wide host range [68], and not all other crops will be effective in 
suppressing them. There are also pathogens such as Bipolaris sorokiniana that require several years without the host plant to be effective [67].

\subsection{Intercropping}

The practice of growing multiple crops in space at the same time is known as intercropping [69,70]. The hypothesis is that when grown together, certain plant species use resources complementarily and more efficiently despite the competition. This efficiency can be measured by the Land Equivalent Ratio (LER) indicator, which is defined as the relative area needed to achieve the same yield as in intercropping when growing two crops separately under the same conditions. The LER value over 1 suggests that there is a benefit from mixing. The intercropping of cereals with legumes is the most common combination in Europe, with legumes being sown at the same time or just before cereals. Numerous field experiments have confirmed the positive effects of such interactions [71-75]. According to Andersen et al. [76], intercropping peas with canola (rapeseed) produces greater productivity gains than for most common barley/pea mixtures.

Silvoarable agroforestry systems present another form of intercropping, where strips of widely spaced trees are incorporated into arable land [77]. In the past, this type of farming was widely practiced in Europe, with trees diversifying the farmer's income with fruits, fodder and wood, preventing wind and water erosion, and providing shade for farm workers and livestock [78]. The most common silvoarable cropping systems in Europe are arable crops grown together with poplars (Populus sp.) or willows (Salix sp.) for biomass production [79,80]. These systems were shown to provide better land-use efficiency ratios than cereals or trees grown as the sole crops. An important limitation of agroforestry systems of particular relevance to low-input farming is the risk of negative nutrient balance. Poplars and willows produce a great deal of biomass, which is then exported from the system together with all the embodied nutrients. The problem of nitrogen abundance may be addressed by cultivating leguminous trees, also referred to as Nitrogen Fixing Trees (NFT's) [81]. Research on NFT's in agroforestry has mostly been conducted in humid/sub-humid or arid/semi-arid areas [82]. In Africa, trees such as Gliricidia, Sesbania and Tephrosia have been successfully used to improve maize yields by bringing in nitrogen $[83,84]$. Used to restore degraded land, the black locust tree Robinia pseudoacacia L. has proven to grow well in Europe on contaminated post-mining sites, outperforming the most popular poplars and willows in terms of biomass production [85,86]. Although NFT's could be effective in nitrogen-deficient cropping systems, they will not solve the problem of phosphorus and potassium deficiencies.

Although not a form of intercropping per se, cultivar mixtures are another way to improve land-use efficiency by growing a variety of plants in the same space. Mixed cultivars of crops can provide higher yields than pure stands, as was confirmed in a meta-analysis by Kiaer et al. [87]. As with crop rotation, however, mixing will not always yield positive results. The meta-analysis shows the range of effects between $-30 \%$ to $+100 \%$, depending on the growing period and the species mixed. Functionally chosen cultivar mixtures can be used to control common diseases such as powdery mildews and rusts [88], but special care must be taken to choose the right varieties and sowing densities.

To date, the applications of LCA to intercropping systems are rare. Table S4 shows the results of a one-year experiment with wheat and pea intercropping in France [89]. Growing the two crops together 
produced reductions in environmental impacts per tonne of wheat ranging from $15 \%$ in the case of eutrophication to $60 \%$ for GWP, despite the increased energy requirements for grain separation. One interesting result was the greater reduction under the "zero nitrogen fertilization" conditions, presumably due to the greater effectiveness of biological nitrogen fixation. The study, however, was based on a one-year experiment, and crop yield under zero-fertilization conditions would most likely decrease over time, offsetting the environmental improvement.

\subsection{Breeding}

Production can be increased in a cropping system by switching from a cultivar with a poor performance to a better-adapted one. Plants with improved genotypes may be more resistant to pathogens and environmental stresses, or make more efficient use of nutrients and water. Environmental improvements in breeding are highly dependent on breeding targets, however. Table S5 shows the results of studies simulating the effects of different breeding strategies on the results of Life Cycle Assessment. Williams et al. suggested that the increased protein content of wheat would reduce post-harvest waste owing to the higher overall quality of the wheat, but would also require additional $\mathrm{N}$ input per tonne, which reduces most environmental benefits [29]. A 20\% improvement in yield was shown to be a more effective breeding target, reducing all of the impact categories considered. Tuomisto et al. [55] investigated yield-improvement scenarios of $44 \%$ and $65 \%$, due to breeding, and showed that these can reduce GWP and energy use by 31\%-48\%. Mcdevitt et al. [90] examined a range of breeding targets in order to identify which would be the most effective in reducing the environmental impacts of porridge-oat production. Improvement of physical yield was shown to be the most effective for reducing many impact categories, followed by reductions in cooking energy (which can be achieved by altering crop viscosity and water absorption) and nitrogen requirement. Breeding for resistance affected toxicity-related impact categories. The study, however, only took into account constant improvements in all properties (10\% yield, 10\% less herbicide needed, etc.). In practice some of these targets would be more difficult to achieve than others, whilst some could be achieved simultaneously. In addition, there are positive feedback mechanisms between a number of breeding targets and other strategies for sustainable intensification-for example, more-resistant cultivars in low-input systems would bring about improved yields, and might enable the adoption of more-resource-efficient techniques such as no-tillage.

Although the importance of breeding for sustainable intensification is well recognised [14-16], just which varieties should be used in low-input farming systems with their increased stress levels is the subject of debate. Since modern cultivars were selected under the rich supply of inputs - mineral fertilizers, pesticides and irrigation water-some scientists argue that these might not be optimal for low-input systems. This is supported by the argument that the traits of particular importance in stressful environments - disease resistance and nitrogen, phosphorus and water-use efficiencies - can be overlooked during the conventional breeding process under high-input conditions, where most limiting factors are eliminated [91-94]. Others question this hypothesis, claiming that varieties developed under optimal growing conditions will also most likely be the best performers in stressed environments $[95,96]$, so that special selection under conditions of reduced fertilization is unnecessary. To provide an answer to this question, a number of special breeding programmes have recently been 
launched for organic and low-input agriculture. Using modern breeding techniques such as marker-assisted selection, useful traits can be introduced into modern cultivars from old varieties, from similar species, or - with the use of genetic engineering — from a wide range of other organisms, including non-plants. Currently, glyphosate resistance is the most widespread trait introduced by genetic engineering. These varieties are of no use under low-input conditions, where pesticides are absent. However, insect-resistant crops - developed by engineering the protein of Bacillus thuringiensis bacteria into plants - were shown to improve yields and potentially provide environmental benefits by reducing the need for insecticides [97-99]. Since increased pest pressure is one of the key limiting factors in low-input farming systems, these crops could potentially be of interest.

\subsection{Recycling Biomass}

Nutrients in plant residues, manures and other organic materials can be recycled either via direct incorporation into the soil, or via the composting process and the application of decomposed organic matter onto fields. European low-input farmers frequently produce and apply composts made of on-farm materials, such as woodchips, bark, manure, straw, crop residues and surplus grass [100]. The application of nitrogen in the form of manure or compost will be characterized by lower energy use per $\mathrm{kg}$ of $\mathrm{N}$ applied than mineral fertilizer, but sometimes higher eutrophication and acidification due to the higher risk of ammonia leaching [23]. Although on-farm composts can be very effective in supplying nutrients, improving soil quality and increasing yields [101], they have their limitations. Soluble nutrient content may be relatively low, depending on substrate composition, composting techniques chosen, and the length of the composting process. During decomposition there will also be some nutrient leaching, as well as emissions of nitrous oxide and methane, both of which are potent greenhouse gases. Instead of being directly incorporated or composted, harvest residues and manures can be used as a feedstock for biogas production, with the remaining digestate spread onto the fields as a fertilizer. The fertilizing value of digestate is dependent upon the feedstock used, but the digestate is generally characterized by higher ammonia content, higher $\mathrm{pH}$ and lower $\mathrm{C}: \mathrm{N}$ ratio than the substrate [102].

Table S6 provides a review of LCA studies concerning the agricultural use of spent digestate. Anaerobic digestion technology has primarily been researched as an option for managing organic waste or producing energy, as is clearly reflected in the choice of functional units for these studies (Table S6). Kong et al. [103] compared four organic-waste-treatment scenarios with LCA in California. All systems analyzed provided negative emission balances, and AD was shown to result in a greater reduction of greenhouse-gas emissions than composting, but a lower reduction than landfill with gas collection. Demonstrated reductions were due to the replacement of energy from fossil fuels, but also to assumed carbon-sequestration effects from applying organic nutrients to soils, for which solid evidence is currently lacking [104]. By contrast, no account was taken of potentially avoided emissions owing to the replacement of other fertilizers, or emissions arising from other uses of organic waste. Poeschl et al. [105] compared the environmental impacts of various AD feedstocks in Germany. In their study, credits were given for replacing electricity from fossil fuels, as well as for replacing mineral fertilizers that would otherwise be applied to the fields. Negative greenhouse-gas emission balances were found for all options except grass silage and whole wheat-plant silage, and considerable differences in achievable reductions were spotted between different feedstocks. Despite the need for 
sterilization, substrates produced from industry waste were shown to be the most effective in reducing greenhouse-gas emissions, followed by straw, corn silage and cattle manure. Corn silage, however, has been shown to cause major land-use-related impacts, since the crop is cultivated purely for bioenergy production [105]. Lansche and Müller [106] pointed out that using cattle manure for anaerobic digestion prevents emissions from the on-farm storage of manure. However, fertilizers are not replaced as in the case of corn or grass silage, since the nutrients from the manure would in any case be applied to the fields. Under such assumptions, cattle manure was still shown to provide the highest reduction in GHG emissions, owing to the avoidance of storage emissions. The study also showed that unlike corn or grass silage, pure cattle manure provides negative eutrophication and acidification balances [106]. Tuomisto et al. [55] investigated the effect of switching from mineral fertilizers to the application of spent digestate from food waste as one of the scenarios for wheat-crop rotation in the UK. Yielding a 54\% reduction in energy demand and a $64 \%$ reduction in GWP per tonne of harvested wheat, this option was the most effective in reducing environmental impacts out of all investigated scenarios.

Composts and digestates made from waste produced outside the farm can be beneficial (Tables S6 and S7), but entail additional environmental costs arising from their transport. Poeschl et al. [105] calculated transport distances that would reverse the demonstrated positive impacts of anaerobic digestion, showing that maximum transport distances must not exceed $64 \mathrm{~km}$ for cattle manure, $53 \mathrm{~km}$ for corn silage and $229 \mathrm{~km}$ for municipal solid waste (MSW) feedstock. Although such results should not be upscaled directly, they illustrate the importance of bearing in mind transport distances when opting for off-farm waste, including cattle manure, as an environmentally preferable nutrient source.

Organic matter can also be recycled through the process of pyrolysis and the creation of organic material referred to as "biochar". Pyrolysis is a form of decomposition occurring at ideally zero- or low oxygen levels and high temperatures [107]. Like anaerobic digestion, this technique can be used to turn biomass into energy. Biochar can also be made from various types of organic material, including sewage sludge and food waste [108], and has been shown to provide liming effects, improved retention and reduced nutrient leaching [109,110]. Depending on the substrate, it can also be a rich source of soluble nutrients [111]. The main reason for the recent scientific interest in biochar was its carbon sequestration potential. It has been suggested that pyrolysis can potentially preserve more carbon than burning and natural decomposition in a more stable form and therefore mitigate climate change [112]. Using LCA, the use of biochar in agriculture was compared to different waste-management strategies, with the results suggesting high benefits to the environment from the application of this technique as compared to more conventional approaches, owing to the displacement of electricity from fossil fuels and the assumed carbon storage [113,114]. Carbon sequestration benefits have not yet been confirmed in any long-term experiments, however. More evidence is therefore needed before such assumptions on carbon sequestration can be made in agricultural LCA studies.

\section{Other Benefits of Low-Input Systems}

Low-input cropping systems provide a range of public goods and ecosystem services that are not fully quantified in LCA studies. As mentioned previously, some low-input farms act as seed banks, preserving rare cultivars and crop species for future generations. Farmland also has an influence on landscape aesthetics. The important role of low-input systems in the preservation of on-farm 
biodiversity is well recognized [8]. Although there are attempts to incorporate biodiversity in LCA's as one of the life cycle impact categories [39,115,116], biodiversity effects occurring outside of the farm gate are not taken into consideration. Life Cycle Assessment provides useful framework for analysing environmental impacts that can be directly linked to the physical flows of materials throughout the product supply chain. For example, Global Warming Potential can be characterized by the quantity of greenhouse gases released to the atmosphere, whilst aquatic eutrophication can be directly linked to the physical quantity of nitrate and phosphorus released into waters over the product life cycle. Physical characterization makes results for these impact categories easy to scale up and down according to the system boundary and functional unit considered in the study in question (for example 1 tonne, 1 kilogram or 1 gram of wheat). Biodiversity losses are caused by the transformation of habitats, which is itself linked to changes in landscapes. Such effects are difficult to characterize using physical flows. Hence, despite applying LCA, we must also consider the potential negative consequences for ecosystem services while recommending certain interventions for improving eco-efficiency of low-input systems.

\section{Conclusions}

Reducing farm-external inputs may lead to either an improvement or reduction in eco-efficiency, depending on the crop, initial level of inputs, and environmental impacts considered. Since wheat is a nitrogen-demanding crop, its ratio of $\mathrm{N}$ fertilization to eco-efficiency presents an illustrative example. For energy use, it tends to follow a U-shaped curve. This means an optimum fertilization level can be identified above and below which the environmental impact per product unit will increase. For GWP, increased environmental impacts will most likely be observed with increased fertilization. At low fertilization levels, however, increased $\mathrm{N}$ input leads to relatively low increases in GWP, and relatively high increases in productivity. This relationship changes at higher fertilization levels, where additional $\mathrm{N}$ input causes substantial increases in greenhouse-gas emissions. Nutrient-related environmental impacts depend on the type of fertilizer used. Eco-efficiency can be modified by swapping out crops and a number of other changes at the cropping-system design stage. Increasing and reducing external inputs presents only one of the available options.

The main weakness of low-input farming systems is their lower land-use efficiency. Reduced inputs generally lead to reduced physical yields, as expressed in produce mass per area. This does not necessarily equate with a decrease in eco-efficiency, since the overall economic value of outputs can be increased. Nevertheless, the performance of low-input cropping systems can be improved for all impact categories if production per unit of land can be increased without corresponding increases in the environmental impacts. Such "sustainable intensification" in a cropping-system level can be achieved through a number of agronomic interventions, but only under certain conditions.

Intercropping, variety mixtures and crop rotations are examples of strategies that utilize positive interactions between diverse plants to improve eco-efficiency. However, the design and maintenance of diverse, eco-efficient cropping systems is a knowledge-intensive endeavor. To ensure complementarity, species and their varieties must to be carefully chosen according to their functionality. The right balance between productivity and resistance needs to be maintained to maximize input-use efficiency. Productivity can also be affected by sowing density and choice of cultivars. Diverse but poorly designed 
cropping systems will most likely suffer from lower eco-efficiency than simple, homogenous approaches to crop cultivation.

Although eco-efficiency can be improved by using better-adapted cultivars, the effectiveness of this strategy is highly dependent upon the traits that were among the breeding objectives. There is a trade-off between productivity and resistance, but efforts should not be focused on improving just one of these characteristics. In low-input systems, they are both highly relevant to eco-efficiency.

The choice of inputs applied to the cropping system is more important than whether said inputs were produced on- or off-farm, but transport of inputs can also play a role. Eco-efficient cropping systems should strive to recycle nutrients produced on-farm, such as manure and harvest residues, as well as those produced in the surrounding production systems, such as livestock production, households and the food industry. The regional availability of these nutrients will vary and can determine the choice of input. In regions where livestock production is common, manure will be a better option than mineral fertilizer. Conversely, in regions where livestock production is not common, mineral fertilizer may well be a better choice than transporting manure over long distances or introducing animals to provide nutrients. Anaerobic digestion improves the eco-efficiency of nutrient recycling as compared to composting and direct application by eliminating some of the methane and nitrous oxide emissions caused by storing biomass in the open air, and by generating useful electricity and heat.

More research is needed to increase our understanding of the trade-offs between environmental impacts and productivity in low-input cropping systems, and of the strategies for improving the eco-efficiency of these systems. LCA studies on intercropping, silvoarable agroforestry systems and various designs of crop rotations should be conducted to advance the state of knowledge on strategies for improving yields in a sustainable way. More research is needed on the trade-offs between different breeding objectives, as well as on the effects of new seeds on LCA results. Anaerobic digestion deserves more attention from researchers and policymakers in terms of its potential for recycling biomass and improving crop yields, rather than just as an option to utilize organic waste. Biochar appears to be a promising solution, but a long-term experiment is needed to confirm its potential carbon sequestration benefits.

\section{Supplementary Materials}

Supplementary materials can be accessed at: http:/www.mdpi.com/2071-1050/5/9/3722/s1.

\section{Acknowledgements}

The research leading to these results received funding from the European Community's Seventh Framework Programme (FP7/ 2007-2013) under SOLIBAM Grant Agreement № 245058.

\section{Conflicts of Interest}

The authors declare no conflict of interest. 


\section{References}

1. Food and Agriculture Organisation of the United Nations. FAOSTAT Database. Production. Available online: http://faostat.fao.org/ (accessed on 19 July 2013).

2. European Statistical Office. General and Regional Statistics. Available online: http://epp.eurostat.ec.europa.eu/portal/page/portal/eurostat/home/ (accessed on 19 July 2013).

3. Stoate, C.; Boatman, N.D.; Borralho, R.J.; Carvalho, C.R.; de Snoo, G.R.; Eden, P. Ecological impacts of arable intensification in Europe. J. Environ. Manag. 2001, 63, 337-365.

4. Tilman, D.; Cassman, K.G.; Matson, P.A.; Naylor, R.; Polasky, S. Agricultural sustainability and intensive production practices. Nature 2002, 418, 671-677.

5. Liebhardt, W.C.; Andrews, R.W.; Culik, M.N.; Harwood, R.R.; Janke, R.R.; Radke, J.K.; Riegerschwartz, S.L. Crop production during conversion from conventional to low-input methods. Agron. J. 1989, 81, 150-159.

6. Parr, J.F.; Papendick, R.I.; Youngberg, I.G.; Meyer, R.E. Sustainable Agriculture in the United States. In Sustainable Agricultural Systems; Edwards, C.A., Madden, R.L.P., Miller, R., House, G., Eds.; Soil and Water Conservation Society: Ankeny, CA, USA, 1990.

7. Gosme, M.; Suffert, F.; Jeuffroy, M.H. Intensive versus low-input cropping systems: What is the optimal partitioning of agricultural area in order to reduce pesticide use while maintaining productivity? Agric. Syst. 2010, 103, 110-116.

8. Strijker, D. Marginal lands in Europe-Causes of decline. Basic Appl. Ecol. 2005, 6, 99-106.

9. Loyce, C.; Meynard, J.M.; Bouchard, C.; Rolland, B.; Lonnet, P.; Bataillon, P.; Bernicot, M.H.; Bonnefoy, M.; Charrier, X.; Debote, B.; et al. Growing winter wheat cultivars under different management intensities in France: A multicriteria assessment based on economic, energetic and environmental indicators. Field Crop. Res. 2012, 125, 167-178.

10. Bouchard, C.; Bernicot, M.H.; Félix, I.; Guérin, O.; Loyce, C.; Omon, B.; Rolland, B. Associer des itinéraires techniques de niveau d'intrants variés à des variétés rustiques de blé tendre: Évaluation économique, environnementale et énergétique ( In French). Courr. environ. INRA 2008, 55, 53-57.

11. European Environment Agency. Agriculture and Environment in EU-15-The IRENA Indicator Report; European Environment Agency: Copenhagen, Denmark, 2005. Available online: http://www.eea.europa.eu/publications/eea_report_2005_6/(accessed on 14 August 2013).

12. Sebillotte, M. Some Concepts for Analysing Farming and Cropping Systems and for Understanding Their Different Effects. In Proceedings of the 1st Congress of European Society of Agronomy, Paris, France, 5-7 December 1990; Scaife, A., Ed.; European Society of Agronomy: Paris, France, 1990; pp. 1-16.

13. Schmidheiny, S. Changing Course: A Global Business Perspective on Development and the Environment; MIT Press: Cambridge, MA, USA, 1992.

14. Food and Agriculture Organisation of the United Nations (FAO). Save and Grow: A Policymaker's Guide to the Sustainable Intensification of Smallholder Crop Production; FAO: Rome, Italy, 2011.

15. Her Majesty Government. The Future of Food and Farming; The Government Office for Science: London, UK, 2011. 
16. Royal Society. Reaping the Benefits: Science and the Sustainable Intensification of Global Agriculture; Royal Society: London, UK, 2009.

17. Tilman, D.; Balzer, C.; Hill, J.; Befort, B.L. Global food demand and the sustainable intensification of agriculture. Proc. Natl. Acad. Sci. USA 2011, 108, 20260-20264.

18. Godfray, H.C.J.; Beddington, J.R.; Crute, I.R.; Haddad, L.; Lawrence, D.; Muir, J.F.; Pretty, J.; Robinson, S.; Thomas, S.M.; Toulmin, C. Food security: The challenge of feeding 9 billion people. Science 2010, 327, 812-818.

19. Garnett, T.; Appleby, M.; Balmford, A.; Bateman, I.; Benton, T.; Bloomer, P.; Burlingame, B.; Dawkins, M.; Dolan, L.; Fraser, D. Sustainable intensification in agriculture: Premises and policies. Science 2013, 341, 33-34.

20. Huppes, G.; Ishikawa, M. Eco-efficiency and its terminology. J. Ind. Ecol. 2005, 9, 43-46.

21. Finnveden, G.R.; Hauschild, M.Z.; Ekvall, T.; Guinée, J.; Heijungs, R.; Hellweg, S.; Koehler, A.; Pennington, D.; Suh, S. Recent developments in Life Cycle Assessment. J. Environ. Manag. 2009, 91, 1-21.

22. Corson, M.S.; van der Werf, H.M.G. Abstracts of the 8th International Conference on Life Cycle Assessment in the Agri-Food Sector (LCA Food 2012), Saint Malo, France, 1-4 October 2012; Corson, M.S., van der Werf, H.M.G., Eds.; INRA, Rennes: Saint Malo, France, 2012.

23. Tuomisto, H.; Hodge, I.; Riordan, P.; Macdonald, D. Does organic farming reduce environmental impacts?-A meta-analysis of European research. J. Environ. Manag. 2012, 112, 309-320.

24. International Organization for Standardization ( ISO ) . Environmental Management-Life Cycle Assessment-Principles and Framework; International Organization for Standardization: Geneva, Switzerland, 2006; Vol. ISO 14040:2006.

25. Roches, A.; Nemecek, T.; Gaillard, G.; Plassmann, K.; Sim, S.; King, H.; Milà i Canals, L. MEXALCA: A modular method for the extrapolation of crop LCA. Int. J. Life Cycle Assess. 2010, 15, 842-854.

26. Brentrup, F.; Kusters, J.; Lammel, J.; Barraclough, P.; Kuhlmann, H. Environmental impact assessment of agricultural production systems using the life cycle assessment (LCA) methodology II. The application to $\mathrm{N}$ fertilizer use in winter wheat production systems. Eur. J. Agron. 2004, 20, 265-279.

27. Nemecek, T.; Huguenin-Elie, O.; Dubois, D.; Gaillard, G.; Schaller, B.; Chervet, A. Life cycle assessment of Swiss farming systems: II. Extensive and intensive production. Agric. Syst. 2011, 104, 233-245.

28. Hauschild, M.Z.; Wenzel, H. Environmental Assessment of Products; Chapman \& Hall: London, UK, 1998; Volume 2 Scientific Background, p. 565.

29. Williams, A.G.; Audsley, E.; Sandars, D.L. Determining the Environmental Burdens and Resource Use in the Production of Agricultural and Horticultural Commodities; Defra Project Report IS0205; Cranfield University, DEFRA: Bedford, UK, 2006.

30. Cranfield University Centre for Environmental Risk and Futures. Agri-LCI Model. Available online: http://www.cranfield.ac.uk/sas/cerf/lca.html (accessed on 19 July 2013).

31. Flavell, R. Knowledge and technologies for sustainable intensification of food production. New Biotechnol. 2010, 27, 505-516. 
32. Murray, W.J. Sustainable Crop Production Intensification. In Proceedings of the International Scientific Symposium Biodiversity and Sustainable Diets United Against Hunger, FAO Headquarters, Rome, Italy, 3-5 November 2010; Burlingame, B., Dernini, S., Eds.; FAO Nutrition and Consumer Protection Division: Rome, Italy, 2012.

33. World Bank. Investments in Sustainable Agricultural Intensification. In Agricultural Investment Sourcebook. Module 4; The International Bank for Reconstruction and Development/The World Bank:Washington, DC, USA, 2004.

34. Pretty, J. Can ecological agriculture feed nine billion people? Mon. Rev. 2009, 61, 46-58.

35. Cassman, K.G. Ecological intensification of cereal production systems: Yield potential, soil quality, and precision agriculture. Proc. Natl. Acad. Sci. USA 1999, 96, 5952-5959.

36. Doré, T.; Makowski, D.; Malézieux, E.; Munier-Jolain, N.; Tchamitchian, M.; Tittonell, P. Facing up to the paradigm of ecological intensification in agronomy: Revisiting methods, concepts and knowledge. Eur. J. Agron. 2011, 34, 197-210.

37. Pretty, J.N. The sustainable intensification of agriculture. Nat. Resour. Forum 1997, 21, 247-256.

38. Vayssières, J.; Vigne, M.; Alary, V.; Lecomte, P. Integrated participatory modelling of actual farms to support policy making on sustainable intensification. Agric. Syst. 2011, 104, 146-161.

39. Haas, G.; Wetterich, F.; Kopke, U. Comparing intensive, extensified and organic grassland farming in southern Germany by process life cycle assessment. Agric. Ecosyst. Environ. 2001, $83,43-53$.

40. Charles, R.; Jolliet, O.; Gaillard, G.; Pellet, D. Environmental analysis of intensity level in wheat crop production using life cycle assessment. Agric. Ecosyst. Environ. 2006, 113, 216-225.

41. Glendining, M.J.; Dailey, A.G.; Williams, A.G.; van Evert, F.K.; Goulding, K.W.T.; Whitmore, A.P. Is it possible to increase the sustainability of arable and ruminant agriculture by reducing inputs? Agric. Syst. 2009, 99, 117-125.

42. Goglio, P.; Bonari, E.; Mazzoncini, M. LCA of cropping systems with different external input levels for energetic purposes. Biomass Bioenerg. 2012, 42, 33-42.

43. Jarecki, M.K.; Lal, R. Crop management for soil carbon sequestration. Crit. Rev. Plant Sci. 2003, 22, 471-502.

44. Govaerts, B.; Verhulst, N.; Castellanos-Navarrete, A.; Sayre, K.D.; Dixon, J.; Dendooven, L. Conservation agriculture and soil carbon sequestration: Between myth and farmer reality. Crit. Rev. Plant Sci. 2009, 28, 97-122.

45. Soane, B.D.; Ball, B.C.; Arvidsson, J.; Basch, G.; Moreno, F.; Roger-Estrade, J. No-till in northern, western and south-western Europe: A review of problems and opportunities for crop production and the environment. Soil Tillage Res. 2012, 118, 66-87.

46. Lal, R. Soil carbon sequestration impacts on global climate change and food security. Science 2004, 304, 1623-1627.

47. West, T.O.; Post, W.M. Soil organic carbon sequestration rates by tillage and crop rotation: A global data analysis. Soil Sci. Soc. Am. J. 2002, 66, 1930-1946.

48. Kim, S.; Dale, B.E. Environmental aspects of ethanol derived from no-tilled corn grain: Nonrenewable energy consumption and greenhouse gas emissions. Biomass Bioenergy 2005, 28, 475-489. 
49. Borzęcka-Walker, M.; Faber, A.; Jarosz, Z.; Syp, A.; Pudełko, R. Greenhouse gas emissions from rape seed cultivation for FAME production in Poland. J. Food Agric. Environ. 2013, 11, 1064-1068.

50. Syp, A.; Jarosz, Z.; Faber, A.; Borzecka-Walker, M.; Pudelko, R. Greenhouse gas emissions from winter wheat cultivation for bioethanol production in Poland. J. Food Agric. Environ. 2012, 10, 1169-1172.

51. Gelfand, I.; Sahajpal, R.; Zhang, X.; Izaurralde, R.C.; Gross, K.L.; Robertson, G.P. Sustainable bioenergy production from marginal lands in the US Midwest. Nature 2013, 493, 514-517.

52. Baker, J.M.; Ochsner, T.E.; Venterea, R.T.; Griffis, T.J. Tillage and soil carbon sequestration-What do we really know? Agric. Ecosyst. Environ. 2007, 118, 1-5.

53. Blanco-Canqui, H.; Lal, R. No-tillage and soil-profile carbon sequestration: An on-farm assessment. Soil Sci. Soc. Am. J. 2008, 72, 693-701.

54. Iriarte, A.; Rieradevall, J.; Gabarrell, X. Environmental impacts and energy demand of rapeseed as an energy crop in Chile under different fertilization and tillage practices. Biomass Bioenergy 2011, 35, 4305-4315.

55. Tuomisto, H.; Hodge, I.; Riordan, P.; Macdonald, D. Comparing global warming potential, energy use and land use of organic, conventional and integrated winter wheat production. Ann. Appl. Biol. 2012, 161, 116-126.

56. Van der Werf, H.M.G. Life Cycle Analysis of field production of fibre hemp, the effect of production practices on environmental impacts. Euphytica 2004, 140, 13-23.

57. Hocking, P.; Randall, P.; Horst, W.J.; Schenk, M.K.; Bürkert, A.; Claassen, N.; Flessa, H.; Frommer, W.B.; Goldbach, H.; Olfs, H.W.; et al. Better growth and phosphorus nutrition of sorghum and wheat following organic acid secreting crops. Plant Nutr. 2002, 92, 548-549.

58. Muchane, M.; Jama, B.; Othieno, C.; Okalebo, R.; Odee, D.; Machua, J.; Jansa, J. Influence of improved fallow systems and phosphorus application on arbuscular mycorrhizal fungi symbiosis in maize grown in western Kenya. Agrofor. Syst. 2010, 78, 139-150.

59. Pypers, P.; Huybrighs, M.; Diels, J.; Abaidoo, R.; Smolders, E.; Merckx, R. Does the enhanced P acquisition by maize following legumes in a rotation result from improved soil $\mathrm{P}$ availability? Soil Biol. Biochem. 2007, 39, 2555-2566.

60. Gaiser, T.; Perkons, U.; Kuper, P.M.; Puschmann, D.U.; Peth, S.; Kautz, T.; Pfeifer, J.; Ewert, F.; Horn, R.; Kopke, U. Evidence of improved water uptake from subsoil by spring wheat following lucerne in a temperate humid climate. Field Crop. Res. 2012, 126, 56-62.

61. Nemecek, T.; von Richthofen, J.-S.; Dubois, G.; Casta, P.; Charles, R.; Pahl, H. Environmental impacts of introducing grain legumes into European crop rotations. Eur. J. Agron. 2008, 28, 380-393.

62. Chen, S.Y.; Porter, P.M.; Reese, C.D.; Stienstra, W.C. Crop sequence effects on soybean cyst nematode and soybean and corn yields. Crop Sci. 2001, 41, 1843-1849.

63. Crookston, R.K.; Kurle, J.E.; Copeland, P.J.; Ford, J.H.; Lueschen, W.E. Rotational cropping sequence affects yield of corn and soybean. Agron. J. 1991, 83, 108-113.

64. Howard, D.D.; Chambers, A.Y.; Lessman, G.M. Rotation and fertilization effects on corn and soybean yields and soybean cyst nematode populations in a no-tillage system. Agron. J. 1998, 90, 518-522. 
65. Long, J.H.; Todd, T.C. Effect of crop rotation and cultivar resistance on seed yield and the soybean cyst nematode in full-season and double-cropped soybean. Crop Sci. 2001, 41, $1137-1143$.

66. West, T.D.; Griffith, D.R.; Steinhardt, G.C.; Kladivko, E.J.; Parsons, S.D. Effect of tillage and rotation on agronomic performance of corn and soybean: Twenty-year study on dark silty clay loam soil. J. Prod. Agric. 1996, 9, 241-248.

67. Kirkegaard, J.; Christen, O.; Krupinsky, J.; Layzell, D. Break crop benefits in temperate wheat production. Field Crop. Res. 2008, 107, 185-195.

68. Cook, R.J.; Schillinger, W.F.; Christensen, N.W. Rhizoctonia root rot and take-all of wheat in diverse direct-seed spring cropping systems. Can. J. Plant Pathol. Revue Can. De Phytopathol. 2002, 24, 349-358.

69. Vandermeer, J. The Ecology of Intercropping; Cambridge University Press: Cambridge, UK, 1989.

70. Whitmore, A.P.; Schröder, J.J. Intercropping reduces nitrate leaching from under field crops without loss of yield: A modelling study. Eur. J. Agron. 2007, 27, 81-88.

71. Picard, D.; Ghiloufi, M.; Saulas, P.; de Tourdonnet, S. Does undersowing winter wheat with a cover crop increase competition for resources and is it compatible with high yield. Field Crop. Res. 2010, 115, 9-18.

72. Carof, M.; de Tourdonnet, S.; Saulas, P.; Le Floch, D.; Roger-Estrade, J. Undersowing wheat with different living mulches in a no-till system. I. Yield analysis. Agron. Sustain. Dev. 2007, 27, $347-356$.

73. Hauggaard-Nielsen, H.; Andersen, M.K.; Jornsgaard, B.; Jensen, E.S. Density and relative frequency effects on competitive interactions and resource use in pea-barley intercrops. Field Crop. Res. 2006, 95, 256-267.

74. Pelzer, E.; Bazot, M.; Makowski, D.; Corre-Hellou, G.; Naudin, C.; Al Rifaï, M.; Baranger, E.; Bedoussac, L.; Biarnés, V.R.; Boucheny, P.; et al. Pea-wheat intercrops in low-input conditions combine high economic performances and low environmental impacts. Eur. J. Agron. 2012, 40, 39-53.

75. Hauggaard-Nielsen, H.; Gooding, M.; Ambus, P.; Corre-Hellou, G.; Crozat, Y.; Dahlmann, C.; Dibet, A.; von Fragstein, P.; Pristeri, A.; Monti, M.; et al. Pea-barley intercropping and short-term subsequent crop effects across European organic cropping conditions. Nutr. Cycl. Agroecosyst. 2009, 85, 141-155.

76. Andersen, M.K.; Hauggaard-Nielsen, H.; Ambus, P.; Jensen, E.S. Biomass production, symbiotic nitrogen fixation and inorganic $\mathrm{N}$ use in dual and tri-component annual intercrops. Plant Soil 2004, 266, 273-287.

77. Graves, A.R.; Burgess, P.J.; Liagre, F.; Terreaux, J.P.; Borrel, T.; Dupraz, C.; Palma, J.; Herzog, F. Farm-SAFE: The process of developing a plot- and farm-scale model of arable, forestry, and silvoarable economics. Agrofor. Syst. 2011, 81, 93-108.

78. Eichhorn, M.P.; Paris, P.; Herzog, F.; Incoll, L.D.; Liagre, F.; Mantzanas, K.; Mayus, M.; Moreno, G.; Papanastasis, V.P.; Pilbeam, D.J.; et al. Silvoarable systems in europe-past, present and future prospects. Agrofor. Syst. 2006, 67, 29-50.

79. Dupraz, C. Adequate design of control treatments in long term agroforestry experiments with multiple objectives. Agrofor. Syst. 1998, 43, 35-48. 
80. Graves, A.R.; Burgess, P.J.; Palma, J.; Keesman, K.J.; van der Werf, W.; Dupraz, C.; van Keulen, H.; Herzog, F.; Mayus, M. Implementation and calibration of the parameter-sparse Yield-SAFE model to predict production and land equivalent ratio in mixed tree and crop systems under two contrasting production situations in Europe. Ecol. Model. 2010, 221, 1744-1756.

81. Sanchez, P.A.; Buresh, R.J.; Leakey, R.R.B. Trees, soils, and food security. Philos. Trans. R. Soc. B Biol. Sci. 1997, 352, 949-960.

82. Danso, S.K.A.; Bowen, G.D.; Sanginga, N. Biological nitrogen fixation in trees in agroecosystems. Plant Soil 1992, 141, 177-196.

83. Akinnifesi, F.K.; Ajayi, O.C.; Sileshi, G.; Chirwa, P.W.; Chianu, J. Fertilizer trees for sustainable food security in the maize-based production systems of East and Southern Africa. A review. Agron. Sustain. Dev. 2010, 30, 615-629.

84. Ndufa, J.K.; Gathumbi, S.M.; Kamiri, H.W.; Giller, K.E.; Cadisch, G. Do mixed-species legume fallows provide long-term maize yield benefit compared with monoculture legume fallows? Agron. J. 2009, 101, 1352-1362.

85. Grünewald, H.; Böhm, C.; Quinkenstein, A.; Grundmann, P.; Eberts, J.; von Wühlisch, G. Robinia pseudoacacia L.: A lesser known tree species for biomass production. BioEnergy Res. 2009, 2, 123-133.

86. Grünewald, H.; Brandt, B.K.V.; Schneider, B.U.; Bens, O.; Kendzia, G.; Hättl, R.F. Agroforestry systems for the production of woody biomass for energy transformation purposes. Ecol. Eng. 2007, 29, 319-328.

87. Kiaer, L.P.; Skovgaard, I.M.; Østergård, H. Grain yield increase in cereal variety mixtures: A meta-analysis of field trials. Field Crop. Res. 2009, 114, 361-373.

88. Mundt, C.C. Use of multiline cultivars and cultivar mixtures for disease management. Annu. Rev. Phytopathol. 2002, 40, 381-410.

89. Naudin, C.; van der Werf, H.M.G.; Jeuffroy, M.H.; Corre-Hellou, G. LCA Applied to Pea-Wheat Intercrops: The Significance of Allocation. In Proceedings of the 8th International Conference on LCA in the Agri-Food Sector, St. Malo, France, 1-4 October 2012; Corson, M.S., van der Werf, H.M.G., Eds.; INRA-Rennes: St. Malo, France, 2013.

90. McDevitt, J.E.; Milà i Canals, L. Can life cycle assessment be used to evaluate plant breeding objectives to improve supply chain sustainability? A worked example using porridge oats from the UK. Int. J. Agric. Sustain. 2011, 9, 484-494.

91. Phillips, S.L.; Wolfe, M.S. Evolutionary plant breeding for low input systems. J. Agric. Sci. 2005, 143, 245-254.

92. Ceccarelli, S. Specific adaptation and breeding for marginal conditions. Euphytica 1994, 77, 205-219.

93. Ceccarelli, S.; Grando, S.; Hamblin, J. Relationship between barley-grain yield measured in low-yielding and high-yielding environments. Euphytica 1992, 64, 49-58.

94. Fess, T.L.; Kotcon, J.B.; Benedito, A. Crop breeding for low input agriculture: A sustainable response to feed a growing population. Sustainability 2011, 3, 1742-1772.

95. Guarda, G.; Padovan, S.; Delogu, G. Grain yield, nitrogen-use efficiency and baking quality of old and modern Italian bread-wheat cultivars grown at different nitrogen levels. Eur. J. Agron. 2004, 21, 181-192. 
96. Tester, M.; Langridge, P. Breeding technologies to increase crop production in a changing world. Science 2010, 327, 818-822.

97. Kooistra, K.J.; Pyburn, R.; Termorshuizen, A.J. The Sustainability of Cotton. Consequences for Man and Environment; Report 223; Wetenschapswinkel Wageningen Universiteit en Reseachcentrum: Wageningen, The Netherlands, 2006.

98. Park, J.R.; McFarlane, I.; Phipps, R.H.; Ceddia, G. The role of transgenic crops in sustainable development. Plant Biotechnol. J. 2011, 9, 2-21.

99. Sanahuja, G.; Banakar, R.; Twyman, R.M.; Capell, T.; Christou, P. Bacillus thuringiensis: A century of research, development and commercial applications. Plant Biotechnol. J. 2011, 9, 283-300.

100. Leroy, B. Soil Food Web, C and N Transformations and Soil Structure: Interactions and Feedback Mechanisms as a Function of the Quality of Exogenous Organic Matter. Ph.D. Thesis, Gent University, Gent, Belgium, 2008.

101. D’Hose, T.; Cougnon, M.; de Vliegher, A.; Willekens, K.; van Bockstaele, E.; Reheul, D. Farm compost application: Effects on crop performance. Compost Sci. Util. 2012, 20, 49-56.

102. Möller, K.; Müller, T. Effects of anaerobic digestion on digestate nutrient availability and crop growth: A review. Eng. Life Sci. 2012, 12, 242-257.

103. Kong, D.; Shan, J.; Iacoboni, M.; Maguin, S.R. Evaluating greenhouse gas impacts of organic waste management options using life cycle assessment. Waste Manag. Res. 2012, 30, 800-812.

104. Leifeld, J. Low-input farming: A way towards climate-friendly agriculture? Carbon Manag. 2013, 4, 31-41.

105. Poeschl, M.; Ward, S.; Owende, P. Environmental impacts of biogas deployment—Part II: Life cycle assessment of multiple production and utilization pathways. J. Clean. Prod. 2012, 24, 184-201.

106. Lansche, J.; Müller, J. Life cycle assessment of energy generation of biogas fed combined heat and power plants: Environmental impact of different agricultural substrates. Eng. Life Sci. 2012, 12, 313-320.

107. Verheijen, F.G.A.; Jeffery, S.; Bastos, A.C.; van der Velde, M.; Diafas, I. Biochar Applications to Soils. A Critical Scientific Review of Effects on Soil Properties, Processes and Functions, EUR 24099 EN; Office for the Official Publications of the European Communities: Luxembourg, Luxembourg, 2010.

108. Navia, R.; Crowley, D.E. Closing the loop on organic waste management: Biochar for agricultural land application and climate change mitigation. Waste Manag. Res. 2010, 28, 479-480.

109. Lehmann, J.; Joseph, S. Biochar for Environmental Management; Earthscan: London, UK, 2009.

110. Steiner, C.; Teixeira, W.G.; Lehmann, J.; Nehls, T.; de Macedo, J.L.V.; Blum, W.E.H.; Zech, W. Long term effects of manure, charcoal and mineral fertilization on crop production and fertility on a highly weathered Central Amazonian upland soil. Plant Soil 2007, 291, 275-290.

111. Chan, K.Y.; Xu, Z. Biochar- Nutrient Properties and Their Enhancement. In Biochar for Environmental Management: Science and Technology; Lehman, J., Joseph, S., Eds.; Earthscan: London, UK, 2009; pp. 67-81.

112. Lehmann, J.; Gaunt, J.; Rondon, M. Bio-char sequestration in terrestrial ecosystems-A review. Mitig. Adapt. Strateg. Glob. Chang. 2006, 11, 395-419. 
113. Roberts, K.G.; Gloy, B.A.; Joseph, S.; Scott, N.R.; Lehmann, J. Life Cycle Assessment of biochar systems: Estimating the Energetic, economic, and climate change potential. Environ. Sci. Technol. 2009, 44, 827-833.

114. Ibarrola, R.; Shackley, S.; Hammond, J. Pyrolysis biochar systems for recovering biodegradable materials: A life cycle carbon assessment. Waste Manag. 2012, 32, 859-868.

115. Tuomisto, H.L.; Hodge, I.D.; Riordan, P.; Macdonald, D.W. Comparing energy balances, greenhouse gas balances and biodiversity impacts of contrasting farming systems with alternative land uses. Agric. Syst. 2012, 108, 42-49.

116. Jeanneret, P.; Baumgartner, D.U.; Knuchel, R.F.; Gaillard, G. A New LCIA Method for Assessing Impacts of Agricultural Activities on Biodiversity (SALCA-Biodiversity). In Proceedings of the 6th International Conference on LCA in the Agri-Food Sector-Towards a sustainable management of the food chain, Zurich, Switzerland, 12-14 November 2008; Nemecek, T., Gaillard, G., Eds.; Agroscope ART: Zurich, Switzerland, 2008; pp. 34-39.

(C) 2013 by the authors; licensee MDPI, Basel, Switzerland. This article is an open access article distributed under the terms and conditions of the Creative Commons Attribution license (http://creativecommons.org/licenses/by/3.0/). 